\title{
Factors affecting intention to purchase edible bird's nest products: the case of Malaysian consumers
}

\begin{abstract}
Malaysia is the second largest producer of edible birdô nest (EBN) in the world, but it has encountered problems when its main export market, China, imposed a ban on EBN products originating from the country. Edible birdôs nest products are products made of the hardened saliva secretions of swiftlet birds. Purchasing intention of edible birdôs nest products is a vital variable in determining customersô purchasing behavior for these products. This research explores how attitude, subjective norms, and perceived behavioral control can influence the buyerôs intention toward purchasing edible birdôs nest products. A total of 1,361 respondents were interviewed using a structured questionnaire from July to November 2012. Descriptive analysis, factor analysis, and multiple regression were used to analyze the data. Multiple regression analysis shows that attitude, subjective norms, and perceived behavioral control are statistically significant predictors of consumer intention toward purchasing edible birdôs nest products.
\end{abstract}

Keyword: Attitude; Perceived behavioral control; Purchase intention; Subjective norms 